\title{
Tidligere språkstart
}

Av Camilla Bjørke \& Berit Grønn

Korrekt citering af denne artikel efter APA-systemet (American Psychological Association System, 6th Edition): Bjørke, C. \& Grønn, B. (2018). Tidligere språkstart.

Learning Tech - Tidsskrift for læremidler, didaktik og teknologi, (4), 36-64. DOI: $10.7146 /$ It.v4i4.110493 


\section{Abstract}

Med utgangspunkt $\mathrm{i}$ et nasjonalt prosjekt initiert av norske utdanningmyndigeter i årene 2010-2012 tar vi i denne artikkelen for oss tidligere start med fremmedspråk på barnetrinnet. Prosjektet vektla en praktisk-kommunikativ tilnærming til målspråkene. Her belyses, hvilke konsekvenser tidligere språkstart kan ha for elevenes læringsog utviklingsprosess i et femårig perspektiv, fra de startet med fransk, spansk eller tysk på 6. trinn (11 år) til de gikk på 10. trinn (15 år) og skulle starte på videregående skole. Dette inkluderer også, hva elevene opplevde som betydningsfullt og relevant, i språklæringsprosessen og generelt, deres refleksjoner rundt oppnådd kompetanse i overgangen fra barneskole til ungdomsskole og dernest til videregående skole, bevissthet om eget læringsforløp og læringsstrategier samt holdninger til språk og læring. Det empiriske materialet består av en kvalitativ intervjuundersøkelse fra 2015 som inkluderer 60 elever tre år etter prosjektslutt i 2012. Informantene er positive til tidligere start med fremmedspråk, men de har klare meninger om suksessfaktorene; de framholder viktigheten av gode organisatoriske rammebetingelser, og at undervisningen tilpasses deres språknivå og inneholder tilstrekkelige språklige utfordringer. Vi håper, at våre funn vil kunne ha interesse og relevans for språkopplæringen både i dansk og norsk skole.

In this article, we look at early foreign language learning in a Norwegian educational context. From 2010 until 2012, the Ministry of Education initiated and supported a large-scale, national project, which involved pupils aged 11 to 12 years. The project focused on a communicative and action-orientated approach to language learning. The aim of the article is to describe and analyze the consequences of early foreign language learning with regard to the development of communicative skills and the pupils own learning experiences. Three years after the end of the project (2015), we conducted a small-scale research project comprising 60 L2 pupils in French, German, and Spanish (age 15) at the threshold between lower to upper secondary education. The method used for data collection was qualitative in-depth interviews. The purpose was to obtain information about the pupils' own reflections on their own language learning process, their awareness of language learning strategies, and their attitudes towards language learning. We found that the pupils had positive attitudes towards early foreign language learning. However, they had clear opinions about what it takes to succeed or fail. The pupils highlighted two key success factors: The lessons must be adapted to the different language levels and provide sufficient challenges. 


\section{Tidligere språkstart}

\section{Et springbrett for en helhetstenking rundt språk og læring}

\section{Introduksjon}

I perioden 2010-2012 ble det i Norge gjennomført et nasjonalt prosjekt med fremmedspråk på 6. og 7. trinn i regi av Kunnskapsdepartementet: Forsøk med fremmedspråk på barnetrinnet (Fremmedspråksenteret, 2010), heretter kalt forsøket. Prosjektelevene startet med fransk, spansk, tysk, mandarin eller russisk da de var 11 år, noe som er to år tidligere enn når de fleste norske elever starter med fremmedspråk (8. trinn, 13 år). Deltakende språklærere gjennomførte samtidig et toårig etterutdanningskurs med fokus på språkdidaktikk for yngre elever. Vår rolle i prosjektet var todelt: vi bidro til kursets fagdidaktiske innhold og fungerte som lærerutdannere i spansk og tysk.

Det empiriske materialet i foreliggende artikkel er basert på en kvalitativ intervjuundersøkelse gjennomført skoleåret 2014/15. Informantene utgjorde 60 elever på 10. trinn, som alle hadde deltatt i det toårige prosjektet. Formålet med undersøkelsen vår var å få innblikk i elevenes refleksjoner rundt og vurderinger av sin videre språkutvikling i løpet av treårsperioden etter prosjektslutt (2012-2015), og hvilke faktorer som etter deres syn spiller inn ved tidligere språkstart. Vi ønsket å danne oss et klarere bilde av elevenes språklæringserfaringer, hvordan de ulike metodiske tilnærmingene på henholdsvis barne- og ungdomstrinnet hadde påvirket læringsprosessen videre, og hvordan elevene hadde dratt nytte av tidligere start med fremmedspråk, i språkfaget og generelt. Vi mener dermed at funnene fra undersøkelsen kan være av interesse innen både allmenn- og fagdidaktikken, ikke minst fordi elevene gjennom sine beskrivelser og refleksjoner knyttet egne språklæringserfaringer i opplæringsløpet til videre framtidsplaner. Dette kan gi oss verdifull informasjon om, hvor unge språkinnlærere er på vei både språk- og læringsmessig.

I tilknytning til forsøket ble det utarbeidet en egen tidsavgrenset læreplan, Loereplan for forsøk med fremmedspråk på barnetrinnet (Utdanningsdirektoratet, 2010), heretter kalt forsøksplanen. De overordnede målene, struktur og innhold i 
forsøksplanen var i tråd med sentrale føringer i læreplanverket Kunnskapsløftet (LKo6) (Utdanningsdirektoratet, 2006a), der utviklingen av elevens kompetanse i å lære å lære og kommunikativ språkkompetanse står sentralt. I Kunnskapsløftet er fem grunnleggende ferdigheter integrert $\mathrm{i}$ kompetansemålene i alle fag: 1) skriveferdigheten, 2) muntlige ferdigheter, 3) leseferdigheten, 4) regneferdigheten og 5) digitale ferdigheter. Forsøksplanen la særlig vekt på utvikling av de muntlige ferdighetene på målspråket.

Formålet i forsøksplanen var å «gi motivasjon og lyst til å utforske flere språk og kulturer», «stimulere barns intellektuelle, emosjonelle og kulturelle utvikling, og fremme deres språklige bevissthet» samt gi elevene innsyn $i$ «hvilke strategier vi bruker for å forstå og bli forstått og hvordan vi lærer nye språk» (Utdanningsdirektoratet, 2010). Det var sentrale føringer for, hvordan undervisningen i faget skulle legges opp i og med, at den skulle ha en praktisk tilncerming; elevenes kommunikative språkkompetanse skulle styrkes nettopp ved at eleven brukte språket: «Å lære et fremmedspråk dreier seg først og fremst om å bruke språket - å lese, lytte, snakke og skrive. Dette oppnås gjennom en aktivitetsrettet tilnærming og ved å ta språket i bruk i opplæringen fra første stund» (Utdanningsdirektoratet, 2010). Videre skulle elevene oppleve og ta del i målspråkområdenes kultur gjennom bruk av tekst, bilder, film eller musikk, noe som ga muligheter for en tverrfaglig tilnærming, f.eks. i fagene musikk, mat og helse, og kunst og håndverk. Og sist, men ikke minst skulle elevene rustes til videre opplæring i fremmedspråk på ungdomstrinnet: «Gjennom å møte flere fremmedspråk allerede på barnetrinnet, vil elevene styrke sin generelle språkkompetanse og få et bedre grunnlag for et bevisst valg av fag på ungdomstrinnet» (Utdanningsdirektoratet, 2010).

Forsøket skulle altså bidra til å styrke elevenes kommunikative språkkompetanse og øke deres bevissthet om strategier for læring. Det skulle også fremme autonomi for, at eleven skulle bli i stand til å gjøre selvstendige vurderinger og valg. Vårt overordnede forskningsspørsmål lyder dermed:

\section{Hvordan kan den praktisk-kommunikative tilnærmingen til språk og læring i prosjektet med}


tidligere språklæring danne et godt grunnlag for videre utforsking og analyse av språket og samtidig bidra til å utvikle elevenes generelle læringskompetanse?

I konkretiseringen av forskningsspørsmålet stiller vi følgende tre spørsmål:

Opplevde elevene selv at det språklige grunnlaget fra barnetrinnet ga dem gode muligheter til å utforske språket videre?

På hvilke måter hadde opplæringen i fremmedspråk artet seg forskjellig på barne- og ungdomstrinnet, og hvordan hadde dette påvirket elevenes læringsprosess?

På hvilke måter var elevene bevisste egen språklæringsprosess og læringskompetanse, og hva slags holdninger hadde de til språk og læring?

Vi vil først kort redegjøre for engelsk- og fremmedspråksfagenes plass i den norske grunnopplæringen, bakgrunnen for igangsettingen av det nasjonale prosjektet (2010-2012) og forskningsstudier, som hittil er foretatt innen feltet tidlig fremmedspråkslæring. Deretter presenterer vi teoriene, vi baserte oss på i planleggingen og gjennomføringen av undersøkelsen og i analysen av resultatene.

Etter å ha presentert resultatene av analysen, diskuterer vi elevenes refleksjoner rundt språklæring og kompetanseutvikling.

\section{Bakgrunn for prosjektet}

I norsk skole skilles det mellom fagene engelsk og fremmedspråk, der fag som fransk, spansk og tysk kategoriseres som fremmedspråk. Faget engelsk er obligatorisk for alle elever fra 1. trinn, jfr. Loereplan i engelsk (Utdanningsdirektoratet, 2013). De fleste elevene starter med et fremmedspråk på 8. trinn (13 
år), og de fortsetter opplæringen i det samme språket på nivå 1 de tre årene på ungdomstrinnet, jfr. Loereplan i fremmedspråk (Utdanningsdirektoratet, 2006b).

Stortingsmelding nr. 30 Kultur for loering (Utdannings- og forskningsdepartementet, 2004), som danner grunnlaget for Kunnskapsløftet, åpner for, at skoler kan tilby fremmedspråk på barnetrinnet (s. 48). Det finnes per i dag ingen nasjonal oversikt over, hvor mange skoler som tilbyr dette, men mye tyder på, at tallet er lavt.

Forsøket inngikk i en større politisk satsing både på nasjonalt og europeisk plan for å styrke en helhetlig språkopplæring i grunnopplæringen og i et livslangt perspektiv (jfr. Stortingsmelding nr. 23 Språk bygger broer (Kunnskapsdepartementet, 2008, s. 8; Europarådet, 1998; 2007)). Målene var å øke elevenes språkkompetanse, ikke bare i norsk og engelsk, men i flere språk, og vurdere om fremmedspråk på barnetrinnet skulle gjøres permanent for alle elever på sikt. Satsingen tok blant annet utgangspunkt i internasjonal forskning om fordelene med tidlig språklæring (Edelenbos, Johnstone \& Kubanek, 2006) i tillegg til et tidligere norsk prosjekt (20052007), som understreker, hvor ugunstig det er med det store tidsintervallet mellom engelskopplæring på 1. trinn og fremmedspråksopplæring først på 8. trinn (Speitz, Simonsen \& Streitlien, 2007, s. 12).

Cirka 100 elevgrupper fra hele landet deltok. Elevene mottok undervisning i 2 timer (à 60 minutter) i uken og kunne velge mellom to modeller: introduksjonsmodellen, der elevene fikk smakebiter av flere språk, eksempelvis ett skoleår med fransk og ett med spansk, eller progresjonsmodellen, der elevene konsentrerte seg om ett språk, eksempelvis tysk. Et hovedfunn i følgeforskningen var at alle aktørene var «meget fornøyde med forsøket» (Mordal, Aaslid, Lindemann \& Jensberg, 2013, s. 19). Det ble også uttrykt en intensjon om en oppfølgingsstudie av elevene i overgangen til ungdomsskolen for å få et større informasjonsgrunnlag omkring effekten av forsøket.

I juni 2012 foretok vi en supplerende undersøkelse bestående av kvalitative dybdeintervjuer av 22 spanskelever som hadde fulgt progresjonsmodellen (Bjørke \& Grønn, 2014). Intervjuene foregikk både på norsk og spansk. Resultatene viste, at elevene var på god vei i sin utvikling av reseptive språkferdigheter. De var trygge og selvsikre i møte med målspråket og kunne snakke om kjente, dagligdagse temaer (som familie, venner, skole, nær- 
miljø) og brukte enkle kommunikasjon- og samhandlingsstrategier. Elevene likte den praktiske tilnærmingen til språket, men enkelte ivret etter en mer analytisk tilnærming, f.eks. eksplisitt grammatikkundervisning.

\section{Fag og fagovergripende kompetanser}

Kunnskapsløftet bygger på kompetansebegrepet, slik det defineres i prosjektet Defining and Selecting Competencies (DeSeCo) (OECD, 2005), som skisserer nøkkelkompetanser for fremtidens skole. DeSeCo framhever tre kjernekompetanser: 1) handle autonomt og reflektert, 2) bruke verktøy interaktivt og 3) delta og fungere i heterogene sosiale grupper (Rychen \& Salganik, 2003). Kunnskapsdepartementet er nå godt i gang med en fagfornyelse i Kunnskapsløftet, og i Norges offentlige utredninger, nr. 7, fremheves betydningen av å operere med et bredt kompetansebegrep ved at «[...] kompetanse omfatter både kognitive, praktiske, sosiale og emosjonelle sider ved elevens læring» (NOU 2014:7, 2014, s. 66). Fag og fagovergripende kompetanser utvikles parallelt; i arbeid med fag vil elevene i tillegg til de fagspesifikke kunnskapene og ferdighetene utvikle kompetanser, som kan beskrives som generelle kompetanser, f.eks. lesing, kritisk tenkning, sosiale og emosjonelle kompetanser (Gamlem \& Rogne, 2016, s. 30). I disse inngår holdninger til læring, utholdenhet i læringsarbeidet og samarbeidsevner, da kompetanse kommer i like stor grad fra holdninger og verdier som fra ferdigheter og kunnskaper (NOU 2014:7, 2014, s. 37-38).

Kreativitet er en fagovergripende kompetanse, som er essensiell for menneskets utvikling (Gamlem \& Rogne, 2016, s. 32-33). Dette innebærer å være nysgjerrig, utholdende, fantasifull og samarbeidsvillig (NOU 2015:8, 2015, s. 31). Man kan stimulere til ulike former og uttrykk for kreativitet i læringsaktiviteter ved, at elevene skaper noe eller tenker seg noe (Sternberg, Jarvin \& Grigorenko, 2009).

Et viktig prinsipp i Kunnskapsløftet er, at alle barn og unge skal få anledning til å lære og oppleve framgang, og læringsarbeidet skal tilpasses de ulike forkunnskapene og erfaringene deres. Ifølge Sawyer (2014, s. 5) innbefatter dybdeloering å knytte tidligere ervervede kunnskaper og erfaringer til ny kunnskap, å se mønstre og oppdage underliggende prinsipper, og å reflektere over egen og andres forståelse og læringsprosess (metakognitiv kompetanse). I fremmedspråksfaget bidrar metalingvistisk bevissthet, altså bevissthet om språket som system og språket 
i bruk, ikke bare til en dypere forståelse av målspråket, men også til å se mønstre og oppdage sammenhenger mellom språk (Utdanningsdirektoratet, 2006b).

\section{Praktisk tilnærming i fremmedspråksopplæringen}

Etter Kunnskapsløftet skal fremmedspråksfaget ha en praktisk tilnærming og være for alle elever, ikke bare de teoristerke, noe som var den gjengse oppfatningen om fremmedspråksfaget tidligere (Trebbi, 2005). Deklarativ kunnskap var viktigere enn prosedural kunnskap, og man måtte først lære språkets strukturer før man kunne snakke det. Utover 1980-tallet ble det mer fokus på kommunikativ kompetanse (Canale \& Swain, 1980), men forestillingen om fremmedspråksfaget som et fag for de teoretisksterke, var seiglivet.

Med en praktisk tilnærming skal elevene møte språket i autentiske situasjoner, og undervisningen skal være handlingsorientert, der elevene samhandler med andre ved hjelp av språket (Tornberg, 2015). Dette er i tråd med Europarådets anbefalinger gjennom Det felles europeiske rammeverket for språk (Europarådet, 2001, oversatt til norsk av Utdanningsdirektoratet, 2011). Forsøksplanen vektla elevenes utvikling av muntlig kompetanse gjennom interaksjon og en praktisk-estetisk tilnærming: gjetteleker, rollespill, sang og musikk (jfr. Europarådsrapporten Adressing the age factor (Johnstone, 2002)). Også annen forskning på tidlig språklæring framhever en lekende tilnærming (Pinter, 2006; Muñoz, 2007; Nikolov, 2009).

\section{Teoretiske perspektiver: aldersfaktoren}

I løpet av de siste to tiårene har fremmedspråksfagene i skolen blitt tilbudt på stadig lavere klassetrinn etter anbefalinger fra Europarådet om individuell flerspråklighet (Europarådet, 1998; 2007). Til grunn for disse trendene ligger dessuten forestillingen om, at barn lærer språk raskere og bedre enn eldre barn og voksne. Disse forestillingene hos beslutningstakere, foreldre og lærere kan syntetiseres til slagordet «jo yngre, jo bedre», når det gjelder tidlig start med fremmedspråk. Ikke desto mindre kan denne diskursen (Nikolov, 2009, s. 5) rotfestes i teorien om, at det finnes en kritisk periode for læring av språk, det vil si at evnen til å lære språk bare kan utvikles naturlig i løpet av et avgrenset tidsrom. Mens Lenneberg (1967) utviklet hypotesen om den kritiske perioden, Critical Period Hypothesis (CPH), forkastet andre den- 
ne type idéer, noe som har gjort, at tanken om en eksisterende kritisk alder er omdiskutert.

Uansett ligger tanken om en forekommende CPH til grunn for, at mange land starter tidligere med fremmedspråksopplæringen i skolen (Nikolov \& Djigunović, 2011). I Norge ble engelsk flyttet fra 3./4. trinn til 1. trinn i 1997, og i forbindelse med ny læreplan i Danmark i 2014, ble engelsk flyttet til 1. trinn og tysk/ fransk til 5. trinn (Daryai-Hansen, Gregersen, Revier \& Søgaard, 2015, s. 256).

Nyere forskning innen tidligere språkstart viser, at aldersfaktoren ikke er gitt som en positiv faktor alene, og at det faktisk er eldre barn og voksne som lærer språk fortest (se f.eks. Muñoz \& Singleton, 2011; DeKeyser, 2012; Jaekel, Schurig, Florian \& Ritter, 2017; Pfenninger \& Singleton, 2017; Myles \& Mitchell, 2012; Muñoz, 2009; 2011). De Houwer (2014, S. 14) oppsummerer disse forskningsresultatene med at «the scientific evidence [...] is inconclusive at best and non-existent at worst».

Det er viktig å presisere, at det er forskjell på andrespråksloering ogfremmedspråksloering. Andrespråket er det språket, som snakkes i det landet, man oppholder seg i. Andrespråkslæringen preges av mye uformell og språklig input fra mange rollemodeller med språket som morsmål. Man lærer språket implisitt, det vil si uten undervisning. Mye tyder på, at denne naturalistiske, implisitte måten å lære språk på, avtar med alderen (Hyltenstam \& Abrahamsson, 2003). I det lange løp har de yngste barna en stor fordel sammenlignet med eldre barn og voksne, når det gjelder uttale, intonasjon og morfologisk-syntaktiske ferdigheter på målspråket (Lambelet \& Berthele, 2014, i Daryai-Hansen, Gregersen, Revier \& Søgaard, 2015). I motsetning til andrespråkslæringen foregår fremmedspråkslæringen ikke i målspråksområdet, og den språklige inputen er mer begrenset og forgår som oftest i den formelle opplæringen. Hos eldre elever er imidlertid den analytiske tenkeevnen mer utviklet, de har større evne til å reflektere over tidligere språklæringserfaringer og trekke inn likheter mellom allerede innlærte språk. Eksplisitte forklaringer kan for eldre elever og voksne spille en viktig rolle i språklæringen, fordi de kognitive - og metakognitive - evnene øker med alderen (Dahl \& Vulchanova, 2014).

Alderen for tidlig og sein start med fremmedspråk blir ulikt definert i de ulike studiene som oversiktsartiklene til Huang (2016) og Muñoz \& Singleton (2011) refererer til. Det er stor forskjell på en 6-åring, som ikke har knekt lesekoden og en 10-åring, 
som både kan lese og skrive på minst to språk. Skolen må ta hensyn til de ulike aldersspesifikke fordelene ved språklæring; man kan forvente av 11-åringer, at de kan reflektere rundt læringsarbeidet i et metakognitivt dybdelæringsperspektiv.

Johnstone (2002) konkluderer med, at tid er en viktig faktor for elevenes fremmedspråkslæring: jo mer tid og intensiv undervisning elevene får, desto bedre lærer de fremmedspråket. Det er dermed lite hensiktsmessig å starte tidlig, dersom det kun er snakk om et minimum av tid til fremmedspråk på timeplanen. Myles (2017) påpeker, at overgangen til ungdomsskolen (7. trinn) er en viktig risikofaktor, fordi elevene der blandes sammen med andre elever, som har varierende grad av språkkunnskaper, til dels i ulike språk, noe som kan virke demotiverende for videre språklæring.

I tillegg til tid og aldersspesifikk metodisk tilpasning er eksterne rammebetingelser av stor betydning for, at tidlig språkstart skal lykkes. I ELLiE-prosjektet (Enever, 2011, s. 251), en longitudinell undersøkelse i syv europeiske land om tidlig språkstart, beskrives suksessfaktorene som positive holdninger til fremmedspråk på skolen og i hjemmet, sammenheng og progresjon mellom trinnene og god informasjon mellom lærerne i overgangsfasene. Huang (2016) hevder, at det kan være potensielle ikke-lingvistiske fordeler med tidlig start, når det gjelder kognitiv og sosioemosjonell utvikling og akademiske prestasjoner. Hun etterlyser derfor mer forskning rundt dette.

\section{Metode}

Funnene våre er basert på resultatene fra en kvalitativ intervjuundersøkelse gjennomført blant fremmedspråkselever på 10. trinn skoleåret 2014/15, som alle hadde deltatt i forsøket. Som nevnt innledningsvis var intensjonen å undersøke, hvordan elevene hadde bygd videre på den lærings- og fremmedspråkskompetansen, de hadde utviklet på 6. og 7. trinn. I planleggingsfasen tok vi utgangspunkt i resultatene fra småskalaundersøkelsen i 2012 (Bjørke \& Grønn, 2014). For å få et større datagrunnlag tok vi kontakt med skoler og lærere, som vi visste hadde deltatt i forsøket, og endte opp med 60 elever fordelt på seks ulike klasser (tre klasser i spansk, to i tysk og en i fransk) ved fem skoler i fire forskjellige fylker. I utformingen av undersøkelsen la vi opp til semistrukturerte fokusgruppeintervjuer i mindre grupper på to til fem elever, da vi ønsket gi rom for erindring og reflek- 
sjon i felleskap (Jacobsen, 2015, s. 160). Vi laget en intervjuguide med 12 åpne spørsmål fordelt på fire tematiske hovedområder: 1) Egenvurdering, mestring og framtidige planer, 2) Språkferdigheter og strategibruk, 3) Metalingvistisk bevissthet og 4) Læringserfaringer fra forsøket på barnetrinnet. Det første delen fungerte som oppvarmingsspørsmål for å bli kjent med informantene. Vi ba dem kort beskrive, hva de selv mente, de behersket godt i fremmedspråket, og hvilke planer de hadde for neste skoleår i forbindelse med overgang til videregående skole.

I den andre og den tredje delen ba vi elevene beskrive egen strategibruk og hovedforskjellene mellom fagene norsk, engelsk og fremmedspråk. Den fjerde delen utgjorde hoveddelen av intervjuet. Elevene delte minner fra barnetrinnet; de snakket om, hvilke aktiviteter de hadde likt best og hvorfor. Videre reflekterte de over, hvilke faktorer som bør være tilstede for å kunne utnytte grunnlaget fra barnetrinnet og lykkes i faget på ungdomstrinnet, samt hvilke fordeler man som elev kan dra nytte av ved å starte tidligere med fremmedspråk.

Intervjuene ble gjennomført fra oktober 2014 til april 2015 på elevenes skoler. Vi intervjuet hver gruppe én gang i cirka 45 minutter. Vi lot elevene fortelle relativt fritt, respondere på og kommentere hverandres innspill. Vi stilte oppfølgingsspørsmål og ba dem gi konkrete eksempler, når de kom inn på temaer, vi $\emptyset$ nsket de skulle utdype. Den felles refleksjonen ga oss et nyansert bilde av elevenes tanker om egen kompetanseutvikling. Vi tok notater i løpet av intervjuene. Vi utelot fyllord og omformet elevenes uttalelser til kortere formuleringer, der det var hensiktsmessig, men forsøkte å fange essensen i uttalelsene og ikke endre selve meningsinnholdet.

I gjennomgangen og analysen av det innhentede materialet tok vi utgangspunkt i de fire ovennevnte tematiske hovedområdene og la til nye kategorier basert på andre temaer, som informantene hadde brakt på banen. Disse var i all hovedsak av metakognitiv art: planlegging, overvåking og evaluering av eget læringsarbeid, faglig progresjon versus stagnasjon, autonomi og muligheter til dybdelæring. Informantenes navn er anonymiserte. 


\section{Resultater}

\section{Organisatoriske rammebetingelser}

Resultatene viser, at det i overgangen fra barne- til ungdomstrinnet var stor variasjon på lokalt nivå $\mathrm{i}$, hvordan undervisningen ble organisert og tilpasset forsøkselevene. Informantene fra fem klasser fra fire av skolene (tre spanskklasser, en tyskklasse og en franskklasse) hadde gått på den samme skolen fra 1.-10. trinn. På 8. trinn kom det nye elever fra tilgrensende barneskoler til alle de fire skolene. Informantene i den sjette klassen (tysk) hadde først gått på en barneskole fra 1.-7. trinn for deretter å bytte til en ungdomsskole fra 8.-10. trinn. Av de seks klassene vi hentet informantene fra, hadde tre av dem beholdt samme lærer i fremmedspråksfaget på ungdomstrinnet, mens de tre andre hadde byttet. Én av spanskklassene hadde byttet lærer både på 8. og 9 . trinn, for deretter å få tilbake den samme læreren som de hadde på barnetrinnet, på 10. trinn. Alle klassene med unntak av én spanskklasse var fra og med 8. trinn sammensatt av forsøkselever og vanlige elever.

\section{Positive opplevelser og språklæringserfaringer}

Elevene hadde mange gode minner fra fremmedspråksundervisningen på barnetrinnet, og de mente, at forsøket hadde gitt dem et godt utgangspunkt for å videreutvikle sine kunnskaper og ferdigheter på ungdomstrinnet. De hadde særlig likt den praktiske tilnærmingen og fremhevet læringsaktiviteter, som involverte mye muntlighet, lek, bevegelse, fysisk aktivitet, dramatisering, sang og dans. Elevene husket og beskrev detaljert en rekke aktiviteter, som involverte bruk av målspråket, ikke bare i klasserommet, men også på andre læringsarenaer som i gymsalen, på sang- og teaterscenen, på skolekjøkkenet, på skolens uteområder og i nærområdet. Eksempelvis fremførte de sanger i fellessamlinger på skolen, de laget teateroppsetning om Rødhette og ulven for yngre elever, de kledde seg ut, hadde moteoppvisning og presenterte plaggene, hadde leker på skolens uteareal for å lære farger og tall, og de brukte skogen bak skolen som location, da de laget videosnutter. Elevene uttrykte tydelig, at den praktiske og aktivitetsrettede tilnærmingen bidro til lærelyst og at den hadde positiv innvirkning på faglig progresjon, særlig når det gjaldt å bygge opp et grunnleggende vokabular: 
Vi gjorde noe samtidig som vi sa noe, og slik husket vi bedre og lærte nye ord. (Maria, 15 år)

99

Vi laget videosnutter, lekte klokkeleken, f.eks. Da syntes vi selv, at vi hadde mer progresjon. (Charlotte, 15 år)

99

Da vi laget skuespill, gjorde vi noe samtidig som vi sa noe, slik lærte vi bedre nye ord. (Thomas, 15 år)

De samme ordene og frasene ble gjentatt på forskjellige måter og $\mathrm{i}$ ulike kontekster, noe som bidro til, at elevene husket dem bedre. Eksempelvis ble ordinnlæringen forsterket ved, at de lyttet til og sang sanger på målspråket og tok sine kreative evner i bruk i språklig egenproduksjon:

99

Vi hørte mye på sanger, da lærte vi nye ord. (Helene, 15 år)

99 På barneskolen gjorde vi mange forskjellige ting, og vi gjentok de samme ordene igjen og igjen da vi sang sanger, da vi hadde rollespill, da vi lekte Color, color ... (Simen, 15 år)

99

Det var gøy å lage dialoger, dramatisere eventyr; da husker man bedre. (Martin, 15 år)

Elevene understreket, at mange av temaene, de hadde jobbet med på barnetrinnet, var temaer, som gikk igjen i språkundervisningen på ungdomsskolen, men da på et mer avansert nivå. De fikk derfor stadig bruk for ordene, de hadde lært på barnetrinnet, og denne formen for repetisjon bidro til konsolidering og memorering av ordkunnskapen. Ordlageret de hadde bygd opp i løpet av forsøket frigjorde kognitiv kapasitet, slik at de kunne fordype seg i andre aspekter ved språket på ungdomstrinnet:

99 Når vi jobber med steder og land, er det mange ord, som går igjen - capital, ciudad. (Ida, 15 år)

99 Vi leser, hører, skriver og sier de samme ordene flere ganger; det går liksom i ring, da husker vi det. (Martine, 15 år)

99 På barneskolen lærte vi mange ord, så vi kunne basic'en. Da ble det lettere for oss på ungdomsskolen å konsentrere oss om andre ting i språket. (Carina, 15 år) 
Den store vektleggingen av muntlig interaksjon i forsøket hadde gjort, at elevene behersket en rekke samtaleregulerende ord og standardfraser, som de kunne ty til, når de ikke forstod, hva samtalepartneren sa, som No comprendo ('Jeg forstår ikke'), Repite, por favor ('Gjenta, vær så snill'), ¿Qué significa ...? ('Hva betyr ...?'), eller selv manglet ord for å uttrykke seg: ¿Cómo se dice ... en español? ('Hvordan sier man ... på spansk?'). Disse enkle samtalestrategiene hadde blitt såpass innarbeidete og automatiserte på barnetrinnet, at elevene ikke var redde for å kaste seg ut i samtaler på målspråket, selv om de ikke forstod absolutt alt.

Muntlige læringsaktiviteter som informantene nevnte hyppig var f.eks. synging og dramatisering på målspråket, interaktive oppgaver på nett, som involverte lyd, bilde og tekst. Hyppig nevnt var ikke minst det forberedende arbeidet i forbindelse med framføring av muntlige presentasjoner på målspråket, fordi dette ga dem rom til å formulere egne læringsmål, velge arbeids- og presentasjonsmåter selv og være kreative. Det, de særlig likte med det forberedende arbeidet, var, at de fikk tid til å tenke seg om, diskutere idéer med medelever, finne bilder og kombinere disse med tilhørende ord og egenprodusert verbaltekst for å understøtte det muntlige budskapet. De opplevde det som intellektuelt stimulerende og morsomt å skape multimodale tekster innenfor den fremmedspråklige rammen.

Blant andre positive læringsopplevelser nevnte elevene arbeid med lytte- og lesestrategier, særlig hvordan de skulle gå fram i en global tilnærming til ukjente muntlige og skriftlige tekster: De fortalte om førlesingsstrategier som å gjette seg til tema utfra konteksten (tittel, ingress, illustrasjoner), aktivering av egne forkunnskaper om ord, ords betydning og allmennkunnskap for å sikre tekstforståelsen:

99 Hvis jeg ikke forstår, lytter jeg bare videre, jeg hører etter om det kommer noe senere som jeg forstår. Det samme gjør jeg med lesing. (Henrik, 15 år)

99

Først plukker jeg ut ordene jeg forstår, sånn finner jeg sammenhengen. (Kristoffer, 15 år)

Elevene fortalte lite om, hvordan de hadde videreutviklet sine lytte- og lesestrategier på ungdomstrinnet. Noen støttet seg i større grad på sine grammatikk-kunnskaper (deklarativ kunnskap) for å forstå teksten. Én elev trakk fram som eksempel, at hun kom- 
binerer ordgjenkjenning med kunnskaper om orddanning: Ved å skille mellom verbets stamme, som uttrykker betydningsinnholdet, og verbets endelse, som gir informasjon om person, tall og tid, kunne hun gjette seg til meningsinnholdet:

99 Hvis vi kjenner til verbet fra før, er det ikke så farlig om vi ikke får med oss endelsen, for vi forstår jo verbet. (Lisa, 15 år)

Grunnlaget fra barnetrinnet ga elevene noen fordeler i planleggingen av egen læring på ungdomstrinnet: De fikk frigjort tid til å prioritere og jobbe grundigere med andre fag, f.eks. matematikk, som flere syntes var vanskelig. Det ga dem også mulighet til å gå dypere inn på grammatiske temaer i fremmedspråksfaget. Elevene merket selv, at de brukte mindre tid på ordinnlæring og leseforståelse enn de nye elevene.

Elevene var altså fornøyde med, at de hadde utviklet en grunnleggende språkkompetanse og noen elementære læringsstrategier på barnetrinnet. Dette gjaldt særlig ordinnlærings- og memoreringsstrategier. I tillegg hadde det på barnetrinnet blitt etablert et kommunikasjon- og samhandlingsmønster elevene imellom, der de støttet hverandre med tips om ord og formuleringer, hvis en medelev stod fast. På denne måten hadde de blitt mer bevisste fordelene med å samarbeide:

99

Hvis vi sier ting høyt på spansk for hverandre, kan vi høre om det er naturlig. (Irene, 15 år)

99

Vi prøver å finne fram riktig ord sammen, vi sjekker i ordbok eller spør læreren, ikke de andre parene hvis de sitter og prater om noe annet. (Maria, 15 år)

\section{Negative opplevelser og språklæringserfaringer}

Det var en generell tendens til, at forsøkselevene var skuffet over, at det ikke forelå en overordnet plan for elever med forkunnskaper i fremmedspråk i overgangen fra barnetrinnet til ungdomstrinnet. Godt over halvparten hevdet, at de ikke hadde fått undervisning, som var tilpasset deres språklige nivå. Dette gjaldt særlig i fremmedspråksfaget på 8. trinn, men også på 9 . og 10. trinn. Kritikken gikk hovedsakelig ut på, at det var for mye repetisjon og for få språklige utfordringer. I elevenes beskrivelser gikk ord og uttrykk som «kjedelig», «demotivert», «frustrert», «å 
stagnere», «å vente», «å bli holdt tilbake», «faglig stagnasjon» og «bortkastede år» igjen. Hovedårsaken til den faglige stagnasjonen og kjedsomheten var ifølge elevene selv de organisatoriske rammebetingelsene: De opplevde det som ugunstig, at de på 8. trinn ble plassert i samme fransk/spansk/tysk-klasse som elever, som ikke hadde deltatt i forsøket. De store forskjellene i elevforutsetninger førte til stort nivåsprik innad i klassene. Dette ga dem en følelse av å bli fratatt muligheten til å utnytte sitt læringspotensial.

Elevene poengterte, at det var rammefaktorene, det var noe feil med, ikke læreren eller de nye medelevene. Tvert imot uttrykte de empati både for læreren, som fikk mye merarbeid med å tilpasse undervisningen til de store nivåforskjellene, og for de nye elevene, som strevde med å opparbeide seg samme språkkompetanse i løpet av kort tid. De følte omsorg for de nye elevene og påtok seg ansvar og lederskap med å inkludere dem og lære dem målspråket:

99

Jeg er ikke helt sikker på, hva jeg mener om forsøket. Vet ikke; idéen er god, men opplegget helt feil. Jeg mistet motivasjonen, da vi ble blandet med nye elever. (Karoline, 15 år)

99

I starten av 8. trinn var det kjedelig, fordi vi måtte være lærere for de andre. Da kunne vi det meste, men de andre kom fort etter. (Kristin, 15 år)

99 På barnetrinnet ble vi vant til å øve på språket i små grupper, og på 8. trinn lot vi de være med, vi ville vise dem, hvordan de skulle si hei og ha det på spansk, hvordan de kunne bestille mat og noe å drikke osv. (Emil, 15 år)

Én av fokusgruppene på fire elever var veldig opptatt av, at et rigid utdanningssystem hemmet dem i egen utviklings- og læringsprosess. På 9. trinn ønsket de å gjennomføre avsluttende eksamen på nivå 1,jfr. Loereplan for fremmedspråk (Utdanningsdirektoratet, 2006b). Årsaken til dette var, at de følte seg rede til å starte på nivå 2 allerede på 10. trinn, det vil si ett skoleår tidligere enn normert (såkalt forsert løp). De hadde sendt formell søknad om dispensasjon til de regionale utdanningsmyndighetene, men fått avslag. Dette ga dem en opplevelse av å bli motarbeidet fra myndighetenes side, noe som hadde virket svært demotiverende. Også forsøkselevene, som ikke hadde blitt blandet med nye elever på 8. 
trinn, opplevde det som en tvangstrøye, at de gjennom hele ungdomsskolen måtte forholde seg til kompetansemålene på nivå 1:

99

Vi ville avslutte nivå 1 etter 9. trinn. Det fikk vi ikke lov til. Slik kunne vi ha blitt fortere ferdig med et av fellesfagene på videregående. Det tror jeg hadde motivert oss mer.

(Emilie, 15 år)

Elevene i den ene klassen, som byttet fremmedspråkslærer hvert skoleår på alle tre trinnene på ungdomsskolen, opplevde, at undervisningen på 8. trinn lå på et altfor høyt språklig og teoretisk nivå, noe de ikke var beredt til å håndtere. Det største problemet var imidlertid, at den nye læreren ikke hadde kjennskap til eller var villig til å sette seg inn i undervisningsmetodikken og arbeidsmåtene, de var vant med fra barnetrinnet.

Elevene som begynte på en ny ungdomsskole på 8. trinn, ble plassert sammen med elever på 9. trinn i fremmedspråksfaget. Dette var et forsøk fra skoleledelsen sin side på å tilpasse undervisningen elevenes forkunnskaper. Intensjonene var gode, men for disse elevene ble overgangen til en mer tradisjonell og teoretisk tilnærming på 9. trinn for brå. Etter et halvt skoleår endte det med, at de ble flyttet til 8. trinn.

\section{Lingvistisk systemforståelse}

Deltakelsen i forsøket hadde gitt elevene et godt utgangspunkt for å utforske språket i dybden på ungdomstrinnet. Under intervjuet reflekterte flere spanskelever over kompleksiteten i grammatiske konstruksjoner med det spanske verbet gustar ('behage'). Ett eksempel er følgende sitat:

99

Verbet gustar kan være vanskelig. Hvis du bytter ut et lite ord, blir meningen helt annerledes. (Emilie, 15 år)

Det «lille ordet», eleven refererer til, er det indirekte objektspronomenet i trykklett form, som er påkrevd i konstruksjoner med verbet gustar. I sitatet ovenfor forsøker eleven å gi en grammatisk forklaring på, hvorfor betydningsinnholdet i en setning kan endres gjennom valg av pronomen (deklarativ kunnskap).

Elevene reflekterte også over, at det var mer arbeidsomt å lære seg grammatikken i fransk-, spansk- og tyskfaget enn i engelskfaget. Spanskelevene framhevet, at de måtte skjerpe oppmerksomheten for, at verbendelsene skulle bli korrekte.

51 Learning Tech 04 | Fagdidaktiske studier i historie, fremmedsprog og matematik 
Pronominalsystemet på spansk var også en utfordring, fordi ordstillingen ofte er annerledes enn på norsk:

99

Verbene bytter endelser etter person hele tiden på spansk. (Thomas, 15 år)

99

Når vi skal si, hva vi liker på spansk, blir ordstillingen som i norsk og engelsk. (Emilie, 15 år)

Elevene forklarte også, hvordan de utnyttet sin generelle språkkompetanse i møte med nye ord:

99Vi kan ofte si: Tenk på det engelske ordet, så blir det lettere å forstå spansk, f.eks. å overraske, det er surprise, og så blir det sorprende på spansk. Da blir det lettere å huske ordene. (Karoline, 15 år)

De reflekterte over nødvendigheten av å bli eksponert for målspråket i den hensikt å øke språkkompetansen, og at det å lære seg et språk tar tid. I fremmedspråk er mengden tilgjengelig input mer begrenset enn på engelsk:

99

Det er lettere å lære engelsk; vi hører engelsk nesten hele tiden. Det tar tid å lære et språk, du må øve masse. (Emil, 15 år)

\section{Refleksjoner rundt oppnådd språkkompetanse i overgangen til videregående opplæring}

Når det gjaldt elevenes forventninger om overgangen fra ungdomstrinnet til videregående skole, uttrykte elevene en blanding av høy tillit til og usikkerhet rundt egen språkkompetanse. På den ene siden antok de, at de hadde høyere kompetanse i fransk/ spansk/tysk enn gjennomsnittet blant elever på 10. trinn. På den annen side var de veldig spente på, hvor høyt nivået i fremmedspråksfaget i videregående opplæring ville bli, hva som ville bli forventet av dem og om deres kompetanse var tilstrekkelig og relevant. Denne dualiteteten kan best illustreres ved det nevnte eksemplet om repitisjon; mange elever syntes, at det var overdrevent mye repetisjon på ungdomstrinnet, noe som i seg selv virket demotiverende. Samtidig så de verdien av å kunne konsolidere opparbeidede kunnskaper og ferdigheter. 
Alt $\mathrm{i}$ alt hadde elevene en gjennomgående positiv holdning til fremmedspråksfaget, fordi de var bevisste på, hva som skulle til for styrke sin språkkompetanse, hvilket også innebærer repetitive øvelser. I tillegg var de bevisste på, at læringsbetingelsene ikke alltid er optimale, og at det i seg selv ikke er ensbetydende med, at man dermed slutter å like faget. Gjennom sine refleksjoner viser elevene modenhet, og at de er i stand til å overvåke og ta kontroll over egen læringsprosess (metakognisjon). Dette resultatet kan følgelig tyde på, at høyere metakognitiv kompetanse kan bidra til å styrke utholdenheten i læringsarbeidet, og at automatisering gjennom repetisjon kan legge et grunnlag for å kunne gå dypere inn i språket (dybdelæring). Elevene vektla også, at tidsaspektet spiller en viktig rolle, når det gjelder å bli en trygg språkbruker; siden de hadde startet med fremmedspråk allerede på 6. trinn, hadde de fått god tid til å bygge opp språkkompetansen sin, og dette var noe de verdsatte i overgangen til videregående opplæring (jfr. Johnstone, 2002).

\section{Analyse}

\section{Fagspesifikke og fagovergripende kompetanser}

Utover de rent fagspesifikke kompetansene hadde elevene også utviklet en rekke fagovergripende kompetanser som lese- og lyttekompetanse, metakognitiv kompetanse, evne til samarbeid, fleksibilitet, kreativitet, kompetanse i problemløsning og kritisk tenkning. De viste relativ høy grad av metakognitiv bevissthet; de verbaliserte såvel positive som negative språklæringsopplevelser og nevnte en rekke faktorer, som hadde vært med på å hemme og fremme egen læring. De hadde klare formeninger om, hvilke metodiske tilnærminger og arbeidsmåter som hadde fremmet læring, og de så store fordeler ved, at de hadde tatt språket i bruk fra første stund (praktisk tilnærming). De hadde også utviklet strategier for å komme videre i egen læring (samarbeidslæring og kreativitet). Deres evne til å reflektere over egen læringsprosess bidro til å ta bevisste valg, når det gjaldt det videre opplæringsløpet. Allerede på 10. trinn så de klart for seg, hvilket fremmedspråk de skulle velge første året i videregående skole. God innsikt i egen utvikling og læring fremmer dybdeforståelse, noe som er i tråd med Sawyer (2014, s. 5), som sier: «Deep learning requires that learners reflect on their understanding and their own processes of learning». 


\section{Muntlighet og ordinnlæring}

Elevene hadde tydelige formeninger om den språkfaglige kompetansen, de hadde bygd opp i løpet av forsøket, og hvordan de hadde videreutviklet denne på ungdomstrinnet. Ifølge elevene hadde den praktiske tilnærmingen i forsøket hatt en positiv innvirkning på egen læring og bidratt til faglig progresjon, særlig med tanke på oppbygging av et grunnleggende vokabular. Her fokuserer vi på tre positive effekter av den praktisk-kommunikative tilnærmingen: 1) Den stimulerte til samarbeid og kreativitet i møte med målspråket, 2) den førte til bedre ordlærings- og memoreringsstrategier og 3) den bidro til å frigjøre kognitiv kapasitet for å kunne arbeide med dybdeforståelse.

Mange av læringsaktivitetene involverte muntlighet, bevegelse og kreativitet, noe som bidro til, at de lærte ord raskere og husket dem bedre. Eksempelvis laget elevene fantasidialoger, der de måtte skape noe samtidig, som de måtte forestille seg noe (jfr. Sternberg, Jarvin \& Grigorenko, 2009). Slik gikk utviklingen av fremmedspråkkompetansen hånd i hånd med utviklingen av kreativ kompetanse (NOU 2015:8, 2015, s. 31). Å lage, øve på og framføre dialogene styrket læringsfelleskapet mellom elevene. Den ene eleven illustrerte dette med følgende utsagn: «Når noen sier ordet høyt, kommer det liksom tilbake til deg». Å konstruere egen kunnskap sammen med andre, leder til dybdelæring: «Deep learning requires that learners understand the process of dialogue through which knowledge is created» (Saywer, 2014, s. 5).

De elementære ordlærings- og memoreringsstrategiene, som elevene hadde tilegnet seg, gikk hovedsaklig ut på å gjenta de samme ordene og frasene (chunks) på ulike måter i ulike kontekster. Disse gjentakelsene fant altså sted i en kommunikativ sammenheng, som ga mening, ikke i form av gjentakelse av meningsløse rekker av ord (glosepugging). Elevene understreket, at det var lettere å lære ordene utenat, når de kunne knytte dem til spesifikke kommunikasjonssituasjoner, som de hadde deltatt i. Dette samsvarer med Tornberg, (2015, s. 126) og von Holst Pedersen (2017, s. 69-70), som påpeker, at kontekstualisering gjør det lettere å lagre ord i langtidsminnet. Den stadige gjentakelsen av ord og fraser fungerte som en automatiseringsprosess, der elevene hentet fram flere ord fra langtidsminnet med stadig mindre anstrengelse: «With practice, what previously required effort and attention, may finally become automatized and routine-like» (Muñoz, 2007, s. 231). 
Vokabularet elevene hadde opparbeidet seg på barnetrinnet, opplevdes relevant. Mange ord, fraser og temaer som de kunne fra før, gikk igjen på ungdomstrinnet, bare på et litt mer avansert nivå. Å inneha et basisvokabular bidro til, at de lettere kunne utvide ordforrådet ytterligere. Å kunne memorere og automatisere ferdigheter frigjorde kognitiv kapasitet til å ta fatt på vanskeligere oppgaver (jfr. Hopfenbeck, 2014, s. 40).

Elevene rapporterte, at det på ungdomstrinnet var stort fokus på læreboka, grammatikk og skriftlighet. Selv om de var klar over, at de nå befant seg på et høyere intellektuelt modningsnivå enn på barnetrinnet og dermed oppdaget nytten av den teoretiske tilnærmingen til språket, savnet de litt av den lekpregete og aktivitetsrettede metodikken fra forsøket, både fordi den krevde mindre anstrengelse og fordi deres språklæringserfaring tilsa, at lek og kreativitet stimulerer til læring. Det å tenke tilbake på forsøket ga dem positive assosiasjoner til språk og læring.

\section{Lytte- og lesestrategier}

I overgangen til ungdomstrinnet hadde elevene profittert på det sterke fokuset på global tilnærming til lytte- og lesetekster i forsøket. I møte med ukjente tekster anvendte de automatisk kompensasjonsstrategier, som bruk av forkunnskaper om ord og verden generelt. Dette ga elevene en opplevelse av faglig trygghet og autonomi i språklæringssituasjonen. De automatisererte leseog lytteferdighetene frigjorde dermed kognitiv kapasitet til å konsentrere seg om meningsinnholdet i teksten, såkalt elaborerende strategier (Hopfenbeck, 2014, s. 39).

Et mindretall av informantene beskrev inngående, hvordan de hadde videreutviklet sine reseptive ferdigheter på ungdomstrinnet, men flere kom inn på, at de nå støttet seg i større grad på sine grammatikk-kunnskaper for å sikre tekstforståelsen. Ut fra det innhentede materialet er det vanskelig å si noe nærmere, om elevene klarte å nyttiggjøre seg denne lytte- og lesekompetansen $i$ andre kontekster og situasjoner. Denne overføringsverdien er noe, man burde forske nærmere på, ikke minst for å finne ut mer om effektene av tidlig start utover det rent fremmedspråksfaglige (Huang, 2016).

\section{Lingvistisk systemforståelse}

Undersøkelsen vår fra 2012 (Bjørke \& Grønn, 2014, s. 11-12) viste, at elevene på 7. trinn (12 år) i stor grad benyttet seg av chunks (formulas) i muntlig kommunikasjon. Eksempelvis brukte de som 
strategi å bytte ut og legge til enkeltelementer i setninger med det spanske verbet gustar ('å behage’). I realiteten dreide dette seg om en relativt avansert grammatisk konstruksjon, men elevene hadde foreløpig lært den i form av chunck. Elevsitatet nedenfor viser dette:

99

Da vi skulle fortelle hva vi likte, sa vi bare me gusta ('jeg liker/det behager meg'), og så puttet vi på den tingen vi likte: Me gusta el fútbol, me gusta el balonmano, me gusta nadar, osv. ('Jeg liker fotball, jeg liker håndball, jeg liker å svømme' osv.) (våre understrekninger) (Emma, 12 år)

Elevene på 7. trinn brukte altså den grammatiske konstruksjonen uten å analysere delelementene, den bestod av. Det skapte språklig selvtillit og trygghet å vite hvilke chunks de kunne ty til, når de skulle uttrykke seg om ting de likte (jfr. a holistic memory orientation, Muñoz, 2007, s. 232). I intervjuene vi gjennomførte i 2014/15, reflekterte elevene derimot over de ulike delelementene, som inngår i grammatiske konstruksjoner med verbet gustar, og hvordan disse fungerer sammen (jfr. a language-analytical orientation, Muñoz, 2007, s. 232). Dekonstruksjonen av chunks (formula) kan altså deles inn i to faser: I den første fasen henger språkinnlæreren et delelement på en fast frase (formula) uten å gå analytisk til verks. I den andre fasen deler hun opp den faste frasen i flere delelementer og undersøker, hvilken form og funksjon hvert enkelt delelement har (Myles, Hooper \& Mitchell, 1998, i Muñoz, 2007, s. 232).

Flesteparten av elevene oppga, at den mer analytiske tilnærmingen til språket på ungdomstrinnet ga dem økt språkforståelse og mestringsfølelse. Men for noen av dem skjedde det motsatte: I det de oppdaget kompleksiteten i målspråkets lingvistiske system, stoppet det opp for dem, og de fikk redusert mestringsfølelse. Disse elevene ble hengende fast i den første fasen av dekonstruksjonen av chunks, som består av å huske enkle fraser og bytte ut ett delelement (overflatelæring). De klarte ikke å finne mønstrene og de underliggende prinsippene (dybdelæring). En analytisk tilnærming til språk tydeliggjør på denne måten faglige nivåforskjeller og den aldersadekvate kognitive utviklingen.

Når det gjelder det komparative aspektet mellom språk, fokuserte vi i intervjuene mest på forholdet mellom norsk, engelsk og fremmedspråk, da dette er fag i skolen. Elevene hadde et metaperspektiv på språkene, og hvilken rolle disse spilte i 
språklæringsprosessen. Flere av elevene behersket andre språk, og utnyttet sikkert denne kompetansen i varierende grad i møte med fransk/spansk/tysk, men dette stilte vi ikke spørsmål om. I etterkant ser vi, at dette er et tema vi kunne ha gått dypere inn i for å skape oss et mer helhetlig bilde av elevenes flerspråklige kompetanse.

\section{Kritisk tenkning og problemløsingskompetanse}

Manglende oppfølging og feil språkstimulering på ungdomstrinnet, særlig i form av overdreven repetisjon, gjorde, at elevene stilte seg kritisk til forsøket. Studier innen fremmedspråkslæring bekrefter, at mangel på tilpasset opplæring og språklige utfordringer fører til stagnasjon, og at for mye repetisjon fører til fossilisering (jfr. Selinker, 1972). Elevenes frustrasjon var først og fremst assosiert med systemsvikt: et utdannelsessystem som ikke var tilpasset deres språklige nivå, forutsetninger og behov. Formelt sett hadde de på 8. trinn startet på nivå 1, jfr. Loereplan $i$ fremmedspråk, men for dem fortonte det seg merkelig: De hadde jo allerede en rekke kunnskaper og ferdigheter i fremmedspråksfaget. Det var derfor betimelig, at elevene stilte spørsmål til hele idéen bak forsøket:

99

På hvilket nivå befant vi oss på 6.-7. trinn? Nivå o? (Emilie, 15 år)

99

Hva var egentlig hensikten med et stort nasjonalt prosjekt, hvis det ikke skulle brukes til noe? Og hvem hadde det gavnet? (Thomas, 15 år)

Gjennom sine kritiske kommentarer betraktet elevene seg selv i utenfra. De så på seg selv som små brikker i et stort utdanningsystem, som ikke var tilpasset dem, noe som gjorde dem mismodige. De hadde inntrykk av, at den kompetansen de hadde oppnådd i løpet av forsøket (2010-2012) formelt sett var verdiløs, og at de hadde dårlige vilkår for å bygge videre på språkkompetansen fra barnetrinnet. Dybdelæring forutsetter, at elevene kan knytte ny kunnskap til tidligere ervervet kunnskap, men hvis elevene ikke tilbys ny kunnskap, er sjansen stor for, at de blir underytere. Saywer understreker betydningen av et læringsmiljø, der elevene kan bygge videre på sin oppnådde kompetanse: «The best way for children to learn is in an environment that builds on their existing knowlegde, if teaching does not engage their prior 
knowlegde, students often learn information just well enough to pass their tests» (Saywer, 2014, s. 3). Dette kan forklare, at mange av våre informanter omtalte 8 . trinn som et bortkastet år.

Til tross for den ovennevnte frustasjonen, viste de samme elevene evne til problemløsning og fleksibilitet. De utnyttet de gode rutinene for samarbeid, som hadde blitt etablert på barnetrinnet til å inkludere de nye elevene, som kom til på 8. trinn. Kommunikasjons- og samhandlingsmønstrene de hadde lært på barnetrinnet, hadde blitt en så naturlig del av læringsprosessen, at de anvendte dem i møte med de nye elevene. De utviste lojalitet og omsorg overfor dem og hjalp dem i gang med målspråket (sosial og emosjonell kompetanse).

\section{Holdninger til språk og språklæring}

I vår undersøkelse av forsøkselevene på slutten av 7. trinn fant vi, at de hadde en utforskende og positiv holdning til egne språkkunnskaper, språk og læring (Bjørke \& Grønn, 2014). Det gode selvbildet og den positive holdningen til egen læringsevne kan delvis forklares med at (yngre) barn har en tendens til å ha en positiv holdning til fremmedspråkslæring, hvis de liker læringsaktivitetene, læreren og atmosfæren i klasserommet (Muñoz, 2007, s. 237). Flere studier har vist, at tidlig start med fremmedspråk ikke bidrar til raskere progresjon og økt læringsutbytte (Muñoz \& Singleton, 2011; De Houwer, 2014; Huang, 2016), men funnene i vår undersøkelse tyder på, at det er med på å sikre et positivt førsteinntrykk av språk og læring og dermed lærelyst og språklig selvtillit. Til tross for negative språklæringserfaringer på ungdomstrinnet hadde våre informanter bevart noe av sin positive holdning til språk og læring. Flesteparten gledet seg til å fortsette med fremmedspråk i videregående skole. Noen av dem så på forsøket som en mulighet til å lære seg flere språk i løpet av grunnopplæringen (i tråd med Europarådets anbefalinger), mens andre så på forsøket som en god anledning til å kunne fordype seg i ett og samme språk over tid:

99

Jo tidligere vi begynner, jo flere språk lærer vi. Jeg hadde tysk på barnetrinnet, har fransk nå, og vil velge spansk neste år. (Truls, 15 år)

99

Jeg er helt sikker på, at jeg vil velge spansk i videregående. Jeg har lært spansk i fem år og vil lære mer. (Linnea, 15 år) 
Elevsitatene viser, at fors $ø$ ket har gitt elevene et bedre grunnlag for valg av språkfag, ikke bare i overgangen til ungdomstrinnet, men også til videregående skole, noe som er en mer langvarig effekt enn den opprinnelige intensjonen i fors $ø$ ksplanen. Samtidig viser den manglende oppfølgingen på 8. trinn, at det kanskje skulle vært utarbeidet en nasjonal plan for, hvordan forsøkselevene skulle følges opp på ungdomstrinnet. På den måten hadde de fått utnyttet sitt læringspotensial mer optimalt.

\section{Konklusjon og perspektivering}

Læreplanen for det nasjonale forsøket med fremmedspråk på 6. og 7. trinn vektla en praktisk-kommunikativ tilnærming til målspråkene, bevissthet rundt egen språklæring og grunnleggende ferdigheter. Ved å ta språket i bruk fra første time, særlig gjennom deltakelse i muntlige læringsaktiviteter, skulle elevene stimuleres til videre utforsking av språk og kultur, både på et intellektuelt og emosjonelt plan. Siden utvalget i vår undersøkelse er lite, er det vanskelig å trekke noen generelle konklusjoner. Elevenes betraktninger i det empiriske materialet viser dog noen gjennomgående trekk. Som et viktig funn vil vi framheve elevenes opplevelse av at fremmedspråksundervisningen på ungdomstrinnet ikke var tilstrekkelig tilpasset deres forkunnskaper fra fremmedspråksopplæringen på 6. og 7. trinn. I følge elevene skyldes dette til dels de mangelfulle organisatoriske rammebetingelsene, noe som igjen førte til, at læringsbetingelsene ikke var optimale, og at elevene ikke fikk utforsket språket videre i så stor grad, som de uttrykte ønske om.

Elevene var generelt positive til den nasjonale satsingen med tidligere språkstart, men var kritiske til at det ikke forelå noen nasjonal og mer helhetlig plan for deres videre opplæringsløp innen fremmedspråk. Prosjektet med tidligere språkstart var en nasjonal satsing i regi av Kunnskapsdepartementet, mens oppfølgingen av prosjektelevene i overgangen fra barnetrinnet til ungdomstrinnet derimot foregikk på kommunalt plan. I forbindelse med det nasjonale prosjektet ble det gjennomført følgeforskning initiert av sentrale utdanningsmyndigheter, der det ble antydet en oppfølgingsstudie av de deltakende elevene i forsøket i overgangen til ungdomstrinnet (Mordal et al., 2013, s. 19). Dette ble aldri realisert. Vi vil derfor aldri kunne få vite, hvor langt prosjektelevene faktisk ville ha nådd i sin språk- og kompetanseutvikling, hvis lærings- og rammebetingelsene hadde 
vært bedre. Det finnes derfor lite forskningsbasert kunnskap om effekten av forsøket i et lengre tidsperspektiv, og denne intervjuundersøkelsen kan være et lite bidrag i så måte.

Elevene anså det språklige grunnlaget, de hadde opparbeidet seg på barnetrinnet som et godt utgangspunkt for videre utforsking av språket, men at mangelen på tilstrekkelige språklige utfordringer på ungdomstrinnet gjorde det vanskelig å utnytte dette læringspotensialet maksimalt. I et retrospektivt perspektiv verdsatte elevene likevel muligheten de fikk til å møte målspråket i ung alder, ta det i bruk og utfolde seg kreativt $\mathrm{i}$ undervisningen. Dette kan være én av forklaringene på, at de i det store og det hele uttrykte en positiv holdning til språk og læring. Gjennom den lekpregede, praktisk-estetiske tilnærmingen og vektlegging av muntlighet på barnetrinnet opparbeidet elevene seg et basisvokabular og en grunnleggende kommunikasjons- og strategikompetanse. Denne dro de nytte av på ungdomstrinnet, der undervisningen var mer preget av skrive- og leseaktiviteter, lingvistisk systemforståelse og læringsaktiviteter tilknyttet læreverk. Som en av fordelene med tidligere språklæring trakk elevene fram, at de fikk god tid til å automatisere grunnleggende kommunikative språkferdigheter, noe som bidro til frigjøring av kognitive krefter til å gå mer analytisk til verks på ungdomstrinnet (dybdeforståelse).

Elevenes deltakelse i forsøket bidro til at de hadde tilegnet seg flere fagovergripende kompetanser som empatisk adferd, autonomi og lederskap; overfor de «nye elevene» på 8. trinn utviste de omsorg og tok ansvar for å inkludere dem i læringsarbeidet. Dette er i tråd med det utvidete kompetansebegrepet, som allerede ble lansert i DeSeCo-prosjektet (Rychen \& Salganik, 2003). Parallelt med at elevene utviklet en fagspesifikk kompetanse, oppnådde de en bredere kompetanse som omfattet samarbeidsevne, kreativitet og fleksibilitet (Illeris, 2012; Gamlem \& Rogne, 2016; NOU 2014:7, 2014). Elevene viser modenhet, og at de er i stand til å overvåke og ta kontroll over egen læringsprosess (metakognisjon). Dette kan tyde på, at høyere metakognitiv kompetanse kan bidra til å styrke utholdenheten i læringsarbeidet og skape positive holdninger til språk og læring.

Som nevnt ovenfor kan ikke slagordet «jo før, jo bedre» brukes som argument alene for å starte tidlig med fremmedspråksopplæring i skolen. Det er ikke dermed sagt, at det er bortkastet å bruke ressurser på tidlig start, fordi det blant annet har en klar effekt på elevers selvregulering og positive holdninger til det å 
lære fremmedspråk. I et femårig perspektiv viste elevene, at de var i ferd med å utvikle en rekke kompetanser, som kan være fordelaktige i et livslangt læringsperspektiv. Målene til Europarådet er nettopp, at elevene gjennom tidlig start med fremmedspråk ikke bare skal lære språk, men også utvikle positive holdninger til andre språk og kulturer. For å få et mer fullstendig bilde av effektene av tidlig start er det behov for framtidig empirisk forskning, også på ikke-lingvistiske fordeler (jfr. Huang, 2016). I dagens samfunn preget av språklig og kulturell kompleksitet foreslår Haukås (2018), at det er verdt å undersøke, om tidligere start med fremmedspråk, og dermed et tidligere møte med andre språk, kulturer og tenkemåter, kan gi oss elever - og dermed medborgere - med større toleranse og respekt for mangfold i samfunnet.

\section{Referencer}

Bjørke, C. \& Grønn, B. (2014). Fremmedspråk på barnetrinnet - quo vadis? Acta Didactica, 8(2), art. 11. http://dx.doi.org/10.5617/adno.1134

Canale, M. \& Swain, M. (1980). Theoretical Bases of Communicative Approaches to Second Language Teaching and Testing. Applied Linguistics, 1(1), 1-47. https://doi.org/10.1093/applin/1.1.1

Dahl, A. \& Vulchanova, M. D. (2014). Naturalistic acquisition in an early language classroom. Frontiers in Psychology, 5, art. 329. DOI:10.3389/ fpsyg.2014.00329

Daryai-Hansen, P., Gregersen, A. S., Revier, R. L. \& Søgaard, K. (2015). Tidligere sprogstart: Forskningsanbefalinger og pædagogiske veje at gå. I A. S. Gregersen (Red.), Sprogfag iforandring - pcedagogik og praksis (2. utg.) (s. 247-284). Frederiksberg: Samfundslitteratur.

De Houwer, A. (2014). Early foreign language teaching: some critical remarks and some recommendations. Babylonia, 1(14), 14-21.

DeKeyser, R. (2012). Age effects in second language learning (s. 71-83). I S. M. Gass \& A. Mackey (Red.), The Routledge handbook of second language acquisition (s. 442-460). London: Routledge. https://doi. org/10.4324/9780203808184.ch27

Edelenbos, P., Johnstone, R. \& Kubanek, A. (2006). The main pedagogical principles underlying the teaching of languages to very young children (Final report of the EAC 89/2004, Study of the European Comission).

Enever, J. (Red.). (2011). ELLiE - Early Language Learning in Europe. London: British Council. Lokaliseret den 19. September 2018 på: https://www. teachingenglish.org.uk/sites/teacheng/files/B309\%20ELLiE\%2oBook\%2O 2011\%2OFINAL.pdf

Europarådet. (1998). Recommendation No. $R$ (98) 6 of the Committee of Ministers to Member States concerning Modern Languages. https://doi. org/10.1017/so261444,800013379

Europarådet. (2001). Common European Framework of Reference for Languages: Learning, teaching, assessment. Oversatt til norsk av Utdanningsdirektoratet, 2011. https://doi.org/10.21832/9781847697318-002 
Europarådet. (2007). From linguistic diversity to plurilingual education: Guide for the Development of Language Education Policies in Europe. Lokaliseret den 19. september 2018 på: https://rm.coe.int/CoERMPublicCommonSearchServices/ DisplayDCTMContent?documentId=09000016806a892e

Fremmedspråksenteret. (2010). Forsøk med fremmedspråk på 6. og 7 . trinn 2010-2012. Lokaliseret den 19. september 2018 på: https://www. fremmedspraksenteret.no/nor/fremmedspraksenteret/barnetrinn/ fremmedsprak-pa-barnetrinnet

Gamlem, S. M. \& Rogne, W. M. (2016). Loringsprosesser: dybdeforståelse, danning og kompetanse. Oslo: Gyldendal Akademisk.

Haukås, Å. (2018). Individuelle forskjellar: motivasjon, alder og språktalent. I C. Bjørke, M. Dypedahl \& Å. Haukås (Red.), Fremmedspråksdidaktikk (s. 265-281). Oslo: Cappelen Damm Akademisk.

Hopfenbeck, T. N. (2014). Strategier for loering. Om selvregulering, vurdering og god undervisning. Oslo: Universitetsforlaget.

Huang, B. H. (2016). A synthesis of empirical research on the linguistic outcomes of early foreign language instruction. International Journal of Multilingualism, 13(3), 257-273. https://doi.org/10.108o/14790718.2015.10667 92

Hyltenstam, K. \& Abrahamsson, N. (2003). Maturational constraints in SLA. I C. J. Doughty \& M. H. Long (Red.), Handbook of Second Language Acquisition (s. 539-588). Oxford: Blackwell.

Illeris, K. (2012). Kompetence: hvad, hvorfor, hvordan? Frederiksberg: Samfundslitteratur.

Jaekel, N., Schurig, M., Florian, M. \& Ritter, M. (2017). From early starters to late finishers? A longitudinal study of early foreign language learning in school. Language Learning, 67(3), 631-664. https://doi.org/10.1111/lang.12242

Jacobsen, D. I. (2015). Hvordan gjennomføre undersøkelser? Innføring $i$ samfunnsvitenskapelig metode. Oslo: Cappelen Damm Akademisk.

Johnstone, R. M. (2002). Adressing 'The Age Factor': Some Implications for Language Policy. Strasbourg: Council of Europe, Language Policy Division.

Kunnskapsdepartementet. (2008). Språk bygger broer: språkstimulering og språkopploering for barn, unge og voksne (St.meld. nr. 23, 20072008). Lokaliseret den 19. september 2018 på: https://www.regjeringen. no/contentassets/e78e5e702d464f89bbc2fiaod5f507d7/no/pdfs/ stm20072008002300odddpdfs.pdf

Lenneberg, E. (1967). Biological foundations of language. New York: Wiley. https://doi.org/10.1080/21548331.1967.11707799

Mordal, S., Aaslid, B. E., Lindemann, B. \& Jensberg, H. (2013). To år med fremmedspråk-erfaringer og betraktninger. Sluttrapport $i$ evalueringen av forsøk med 2. fremmedspråk som felles fag på 6.-7. trinn i perioden 2010-2012 (SINTEF-rapport nr. A23743). Lokaliseret den 19. september 2018 på: https://www.fremmedspraksenteret.no/neted/services/ file/?hash=od39ac3aaf94,21c8a4acbefd 57 f66oob

Muñoz, C. (2007). Age-related differences and second language learning practice. I R. M. DeKeyser (Red.), Practice in a Second Language. Perspectives from Applied Linguistics and Cognitive Pshycology (s. 229-255). New York: Cambridge University Press. https://doi.org/10.1017/cbo9780511667275.014.

Muñoz, C. (2009). Input and Long-term Effects of Early Learning in a Formal Setting. I M. Nikolov (Red.), Contextualizing the age factor: issues in early foreign language learning. Berlin: Mouton de Gruyter. https://doi. org/10.1515/9783110218282.141 
Muñoz, C. (2011). Is input more significant than starting age in foreign language acquisition? International Review of Applied Linguistics (IRAL), 49(2), 113-133.

Muñoz, C. \& Singleton, D. (2011). A critical review of age-related research on L2 ultimate attainment. Language Teaching, 44(1), 1-35. https://doi.org/10.1017/ So261444810000327

Myles, F. \& Mitchell, R. (2012). Learning French from ages 5, 7, and 11: An Investigation into Starting Ages, Rates and Routes of Learning Amongst Early Foreign Language Learners (ESRC End of Award Report, RES-062-23-1545). Swindon: Economic and Social Research Council.

Myles, F. (2017). Learning foreign languages in primary schools: is younger better? Languages, Society \& Policy. https://doi.org/10.17863/CAM.9806

Nikolov, M. (Red.). (2009). The Age Factor and Early Language Learning. Berlin: Mouton de Gruyter. https://doi.org/10.1515/9783110218282

Nikolov, M. \& Djigunović, M. J. (2011). All Shades of Every Color: An Overview of Early Teaching and Learning of Foreign Languages. Annual Review of Applied Linguistics, 31, 95-119. https://doi.org/10.1017/So267190511000183

NOU 2014:7. (2014). Elevenes loering ifremtidens skole. Lokaliseret den 19. september 2018 på: https://www.regjeringen.no/no/dokumenter/NOU2014-7/id766593/sec7

NOU 2015:8. (2015). Fremtidens skole. Lokaliseret den 19. september 2018 på: 1ohttps://www.regjeringen.no/ contentassets/da148fec8c4a4ab88daa8b677a700292/no/pdfs/ nou2015201500080oodddpdfs.pdf

OECD. 2005. The Definition and Selection of Key Competencies: Executive Summary. Lokaliseret den 19. september 2018 på: http://www.oecd.org/education/skills-beyond-school/ definitionandselectionofcompetenciesdeseco.htm

Pfenninger, S. E. \& Singleton, D. (2017). Beyond Age Effects in Instructional L2 Learning: Revisiting the Age Factor. Bristol: Multilingual Matters. https://doi.org/10.21832/pfenni7623

Pinter, A. (2006). Teaching young language learners. Oxford: Oxford University Press.

Rychen, D. S. \& Salganik, L. H. (2003). Key Competencies for a Successful Life and a Well-Functioning Society. Cambridge, MA: Hogrefe \& Huber Pub.

Sawyer, K. R. (Red.). (2014). The Cambridge handbook of The Learning Sciences. New York: Cambridge University Press. https://doi.org/10.1017/ cbo9781139519526

Selinker, L. (1972). Interlanguage. International Review of Applied Linguistics, 10(3), 209-241. https://doi.org/10.1515/iral.1972.10.1-4.209

Speitz, H., Simonsen, T. \& Streitlien, Å. (2007). Evaluering av prosjektet «Forsøk med tidlig start av 2. fremmedspråk» (Telemarkforsking-Notodden, Rapport 03/2007). Lokaliseret den 19. september 2018 på: https://brage. bibsys.no/xmlui/bitstream/handle/11250/2439978/Rapp2007-03_Tidlig\%20 start.pdf? sequence $=1$ \&isAllowed $=y$

Sternberg, R., Jarvin, L. \& Grigorenko, E. L. (2009). Wisdom, Intelligence, Creativity, and Success. Thousand Oaks, California: Corwin. https://doi. org/10.4135/9781483350608

Tornberg, U. (2015). Språkdidaktik. Malmö: Gleerups.

Trebbi, T. (2005). Det andre fremmedspråket: fra elitefag til et fag for alle? I K. Børhaug, A.-B. Fenner \& L. Aase (Red.), Fagenes begrunnelser (s. 103-113). Bergen: Fagbokforlaget. 
Utdanningsdirektoratet. (2006a). Loreplanverket for Kunnskapsløftet. Oslo: Utdanningsdirektoratet. Lokaliseret den 19. september 2018 på: https://www.udir.no/laring-og-trivsel/lareplanverket/

Utdanningsdirektoratet. (2006b). Loreplan i fremmedspråk. Oslo: Utdanningsdirektoratet. Lokaliseret den 19. september 2018 på: https://www.udir.no/klo6/FSP1-o1

Utdanningsdirektoratet. (2010). Loereplan for forsøk med fremmedspråk på barnetrinnet. Oslo: Utdanningsdirektoratet. Lokaliseret den 19. september 2018 på: https:/www.udir.no/globalassets/filer/tall-og-forskning/ rapporter/2013/fremmedsprak.pdf

Utdanningsdirektoratet. (2011). Det felles europeiske rammeverket for språk: Loring, undervisning, vurdering. Oslo: Utdanningsdirektoratet. Lokaliseret den 19. september 2018 på: https://www.udir.no/Upload/Verktoy/5/UDIR_ Rammeverk_sept_2011_web.pdf?epslanguage=no

Utdanningsdirektoratet. (2013). Lœereplan i engelsk. Oslo: Utdanningsdirektoratet. Lokaliseret den 19. september 2018 på: https://www.udir.no/klo6/ENG1-o3

Utdannings- og forskingsdepartementet. (2004). Kultur for loering (St.meld. nr. 30 2003-2004). Lokaliseret den 19. september 2018 på: https://www. regjeringen.no/no/dokumenter/stmeld-nr-030-2003-2004-/id404433/

von Holst-Pedersen, J. (2017). At lære sprog gennem chunks, leg og bevegelse. I A. S. Gregersen (Red.), Tidlig sprogstart i skolen (s. 66-82). Frederiksberg: Samfundslitteratur. 


\section{Learning Tech - Tidsskrift for læremidler, didaktik og teknologi Udgives af Læremiddel.dk}

Learning Tech er et forskningstidsskrift, hvor alle artikler er forskerbedømt i form af dobbeltblindt peer review. Tidsskriftet bringer artikler, der rammer genstandsfeltet mellem læremidler, didaktik og teknologi, og hensigten er at spille en betydelig rolle som platform for den voksende skandinaviske læremiddelforskning.

\section{Redaktion}

Thomas R.S. Albrechtsen, University College Syd (ansvarshavende redaktør) Anne-Mette Nortvig, Professionshøjskolen Absalon Bettina Buch, Professionshøjskolen Absalon Hildegunn Juulsgaard Johannesen, University College Syd Marie Falkesgaard Slot, UCL Erhvervsakademi og Professionshøjskole René Boyer Christiansen, Professionshøjskolen Absalon Stefan Ting Graf, UCL Erhvervsakademi og Professionshøjskole Stig Toke Gissel, UCL Erhvervsakademi og Professionshøjskole Stine Reinholdt Hansen, UCL Erhvervsakademi og Professionshøjskole

\section{Redaktionssekretær}

Trine Ellegaard, UCL Erhvervsakademi og Professionshøjskole

\section{Temaredaktion}

Thomas R.S. Albrechtsen, University College Syd

Marie Falkesgaard Slot, UCL Erhvervsakademi og Professionshøjskole Hildegunn Juulsgaard Johannesen, University College Syd

\section{Design og grafisk tilrettelæggelse}

Trefold - grafisk design og kommunikation

\section{Tryk}

Grafisk Produktion Odense

ISSN 2445-7981 (Tryk)

ISSN 2445-6810 (Online)

\section{Rettigheder}

(c) 2018 Læremiddel.dk og forfatterne

\section{Kontakt}

Læremiddel.dk, Niels Bohrs Allé 1, 523o Odense M

www.laeremiddel.dk 